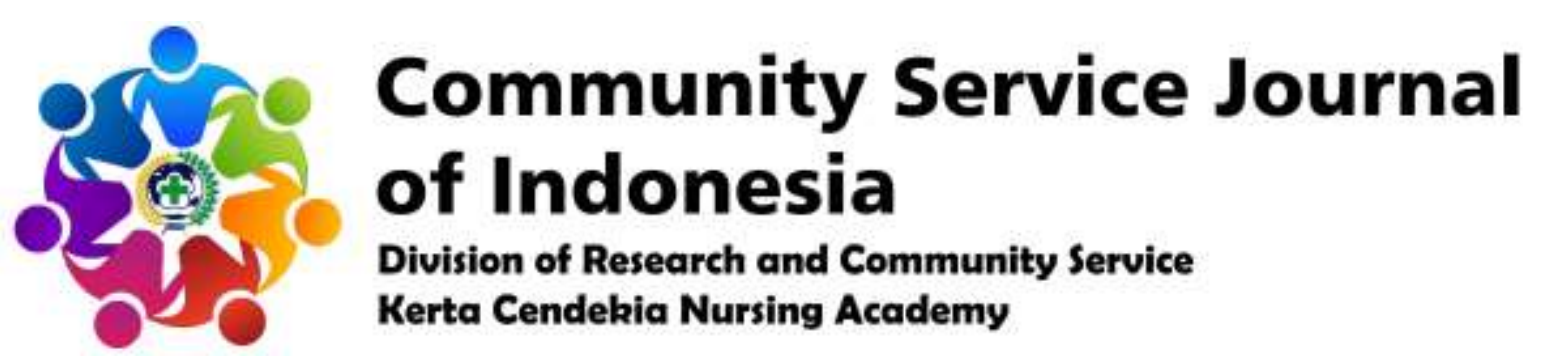

https://ejournal-kertacendekia.id/index.php/csji/index

Community Service Journal of Indonesia 3 (1) (2021): 8-11

Doi: https://doi.org/10.36720/csji.v3i1.286

\title{
MENTAL HEALTH THERAPY TRAINING IN YOUTH
}

\author{
Faida Annisa ${ }^{1 *}$, Nina Rizka Rohmawati ${ }^{1}$, Elok Triestuning ${ }^{1}$
}

${ }^{1}$ Psychiatric and Mental Health Nursing Department, Health Polytechnic of Kerta Cendekia

\author{
* Correspondence \\ Faida Annisa \\ Health Polytechnic of Kerta Cendekia \\ Lingkar Timur Road, Rangkah Kidul Village, Sidoarjo Sub-District, \\ Sidoarjo Regency, East Java Province, Indonesia - 61234 \\ Email: nio_annisa@yahoo.com
}

\begin{abstract}
Community Service Activities in the form of Mental Health Therapy Training for Adolescents is one form of community service in the form of seminars aimed at conveying opinions or something new to participants, namely BK and teachers of Vocational High School in Sidoarjo with the hope that participants will get something new to be developed to become one thing that is broader about mental health therapy in adolescents. The activity was carried out on April 7, 2021 at the Health Polytechnic of Kerta Cendekia, Sidoarjo with the target being BK teachers at the Senior High School and Vocational High School levels in Sidoarjo. Before the activity was carried out, there was a process of preparing activities for 3 weeks before the activity was carried out, starting from the selection of extension materials to submission to related parties. As an evaluation, the activity was attended by BK teachers at the Senior High School and Vocational High School in Sidoarjo. Participants participated in these activities with enthusiasm and conducive, the activities can be carried out on time smoothly.
\end{abstract}

Keywords: Mental health, therapy, youth, training.

(C) 2021 The Authors. Community Service Journal of Indonesia Published by Institute for Research and Community Service,

Health Polytechnic of Kerta Cendekia, Sidoarjo

This is an Open Access Article distributed under the terms of the Creative Commons Attribution 4.0 International License

which permits unrestricted non-commercial use, distribution, and reproduction in any medium, provided the original work is

properly cited.

E-ISSN
2684-7884
P-ISSN
$2774-4027$

\section{INTRODUCTION}

The stage of human development after passing through childhood is adolescence. At this time many changes, both physically, psychologically and socially. In the process of mental maturation, humans are always seen as a unified whole of the elements of body, soul, social, not only focused on disease but on improving the quality of life, consisting of the welfare of the body, soul 
and socio-economic productivity. At this time, problems arise that affect mental health including anxiety, stress, past trauma and so on. Adolescent health is important in determining the quality of the nation. Therefore, adolescents must grow up in a conducive and supportive environment.

Data from Riskesdas (basic health research) 2018 shows the prevalence of emotional mental disorders as indicated by symptoms of depression and anxiety for ages 15 years and over reaches around $6.1 \%$ of the total population of Indonesia or the equivalent of 11 million people. Teenagers (15-24 years) have a depression percentage of $6.2 \%$. Severe depression will have a tendency to hurt yourself (self-harm) to suicide. $80-90 \%$ of suicides are the result of depression and anxiety. Suicide cases in Indonesia can reach 10,000 or the equivalent of every hour there is a suicide case. According to a sacred ophthalmologist, $4.2 \%$ of students in Indonesia have thought of committing suicide. Among students, $6.9 \%$ had suicidal intentions while another $3 \%$ had attempted suicide. Depression in adolescents can be caused by several things such as pressure in the academic field, bullying, family factors, and economic problems.

Self-healing technique is a self-healing process from inner wounds. This method is usually done when someone is holding a mental wound that is very disturbing emotions. According to psychology, selfhealing is a healing process that only involves oneself to rise from the suffering that has been experienced and recover from inner wounds. The purpose of self-healing itself is to understand oneself, accept imperfections.

\section{OBJECTIVES}

General Purpose

After the training, the teacher of the Senior High School and Vocational High School in Sidoarjo can understand selfhealing techniques

\section{Special Purpose}

After the training, it is hoped that the teacher of the Senior High School and Vocational High School in Sidoarjo can:

1. Understanding the meaning of adolescent mental health.

2. Understanding self-healing techniques.

3. Understanding cognitive therapy techniques.

4. Apply self-healing techniques and cognitive therapy techniques.

\section{PLAN OF ACTION}

Strategy Plan

The strategy plan implemented, including:

1. Coordinate with the Head of MGBK of the Senior High School and Chairman of MGBK of Vocational High School, Sidoarjo Regency to apply for permission to conduct a Mental Health Therapy Training in Youth as a nursing program activity and to provide guidance to BK teachers for Senior High School and Vocational High School in Sidoarjo Regency.

2. To assign BK teachers to the Senior High School and Vocational High School in Sidoarjo Regency in Mental Health Therapy Training for Youth.

3. Conduct time contracts with BK teachers for the Senior High School and Vocational High School in Sidoarjo Regency.

4. Conducting Training on Mental Health Therapy for Youth. 


\section{Implementation}

Actions taken in the implementation of these activities, including:

1. Contacting the Head of MGBK for the Senior High School and Head of MGBK for Vocational High Schools in Sidoarjo Regency to request a permit for activities and gather BK teachers for the Senior High School and Vocational High Schools in Sidoarjo Regency.

2. Prepare training venues and media.

3. Carry out training activities for BK teachers from the Senior High School and Vocational High Schools in Sidoarjo Regency.

\section{Setting}

This training activity was carried out on April 7, 2021 at the Hall of the Health Polytechnic of Kerta Cendekia, Sidoarjo.

\section{Target}

The main targets in the implementation of this training are BK teachers from the Senior High School and Vocational High Schools in Sidoarjo Regency.

\section{RESULTS AND DISCUSSION}

This training program was held on April 7, 2021, at the Kerta Cendekia Health Polytechnic Hall, Sidoarjo. The training was attended by 50 participants who were BK teachers from the Senior High School and Vocational High Schools in Sidoarjo Regency. The equipment used during the discussion were handouts, laptops, projectors, mics. The use of communicative and applicative language in the implementation of the seminar, the $\mathrm{BK}$ teacher of the Senior High School and Vocational High Schools in Sidoarjo Regency gave a fairly good response to what had been conveyed by the presenter.
The BK teachers for the Senior High School and Vocational High Schools in Sidoarjo Regency were very enthusiastic and worked well together during the seminar. The final evaluation carried out by the organizers of the activity found that $90 \%$ of the training participants were able to understand related to the notion of selfhealing, the purpose of self-healing, the meaning of cognitive therapy, the purpose of cognitive therapy training, as well as practicing the implementation of cognitive therapy. In addition, as many as $85 \%$ of the training participants have also understood about self-healing techniques.

\section{CONCLUSION}

Self-healing training and cognitive therapy techniques are needed to be given to teachers, so that they can help their students in dealing with problems that can affect the psychology of their students.

\section{REFERENCES}

Anindyaputri, I. (2016). Terapi Kognitif dan Perilaku, Konseling untuk Berbagai Masalah Psikologi, Retrieved from https://hellosehat.com/mental/mentallainnya/terapi-kognitif-dan-perilakuuntuk-masalah-psikologis/

Dewi, D.S. (2020). 12 Tips Melakukan Self-Healing untuk Mengatasi Luka Batin. Retrieved from https://tirto.id/12-tips-melalukan-selfhealing-untuk-mengatasi-luka-batinfjiE.

Herawati, S., Kartika, T., \& Rasalwati, U.H. (2017). Penerapan Terapi Perilaku Kognitif dalam Meningkatkan Aktivitas Belajar Anak di Kota Bandung. PEKSOS: Jurnal Ilmiah Pekerjaan Sosial, 16 (2), 215239. 
Kementerian Kesehatan RI. (2018). Riset Kesehatan Dasar Tahun 2018. Jakarta: Balitbangkes Kementerian Kesehatan RI.

Maudhi, A.F. (2021). Self-Healing yang Bisa Dilakukan dengan Mudah. Retrieved from https://www.qubisa.com/article/selfhealing-therapy.

Pramesty, N.A. (2020). 5 Metode SelfHealing yang Patut Dicoba untuk Sembuhkan Luka Batin. Retrieved from

https://www.idntimes.com/life/inspira tion/nadya-ayu/luka-batin-tak-

kunjung-sembuh-coba-lakukan-5metode-self-healing-ini-c1c2/5.

Septiani, D. \& Ervika, E. (2011). Terapi Kognitif Perilaku untuk Mengurangi Masalah Perilaku pada Anak Conduct Disorder. Jurnal Intervensi Psikologi, 3 (1), 97-124. DOI: https://doi.org/10.20885/intervensipsi kologi.vol3.iss1.art5

Wisnubrata. (2020). Self-Healing, Menyembuhkan Luka Batin Sendiri. Retrieved from https://lifestyle.kompas.com/read/202 0/05/29/092426020/self-healingmenyembuhkan-luka-batin-denganbantuan-diri-sendiri?page=all. 